\title{
Managerial Ownership and Corporate Cash Holdings: Insights from an Emerging Market
}

\begin{abstract}
Nida Abdioğlua
Abstract: This paper examines the impact of managerial ownership on cash holding decisions of the firms listed in Borsa Istanbul 100 index between 2005 and 2013. Main aim of the study is to analyse whether there is any evidence for managerial alignment or managerial entrenchment effect on the corporate cash holdings. A non-monotonic relation between managerial ownership and cash holding is found. The findings indicate that managerial ownership aligns the interests of managers with those of shareholders. These firms with managerial ownership prefer to hold less cash. In addition, it is reported that at higher level of managerial ownership, entrenchment effect of managers is seen. Managers practice their own interests at the expense of shareholders' and the firms with higher level of managerial ownership hold more cash. The results also reveal that prior year's cash holding positively affects this year's cash holding. Firm size, liquidity and tangibility are also effective on cash holding decisions of Turkish firms.
\end{abstract}

Keywords: Cash Holdings, Managerial Ownership, Panel Data, Managerial Alignment, Managerial Entrenchment

JEL Classification: G30, G32, G34

\section{Introduction}

The reason of holding corporate cash is explained by four motives in economics and finance literature: the transaction motive, the precautionary motive, the tax motive and the agency motive (Bates, Khale, and Stulz, 2009). Keynes (1936) determines two main benefits for holding cash. First, the firm reduces transaction costs to raise funds and also it does not have to liquidate assets in order to make payments. This is called transaction cost motive (Opler, Pinkowitz, Stulz and Williamson, 1999). According to precautionary motive, in case of cash flow shortfalls a firm might not invest in profitable projects if it does not have liquid assets. As a result, a firm holds cash in order to diminish the costs of financial distress (Opler et al., 1999). Third, Foley, Hartzell, Titman and Twite (2007) report that the firms which incur tax consequences related with repatriating foreign earnings hold more cash. This is explained by tax motive (Bates et al., 2009).

It is assumed that when agency problems between managers and shareholders are greater, cash is worth less (Pinkowitz, Stulz and Williamson, 2006). In his free cash flow theory, Jensen (1986) states that managers have an incentive to hold large amount of cash for their own objectives rather than shareholders'. By doing so, they increase the assets under their control and gain optional power over the firm's investment decisions (Ferreira and Vilela, 2004). However, it is known that when managers have ownership, they aim to

${ }^{a}$ Assist. Prof., PhD., Bandırma Onyedi Eylül University, Faculty of Economics and Administrative Sciences, Balıkesir, Turkiye, nidaabdioglu@balikesir.edu.tr 
maximise firm value rather than using the firm's resources for their own benefits. Thus, managerial ownership aligns the interests of managers and shareholders and this is called as managerial alignment effect. In addition, when managerial ownership continues to increase managers can not be monitored by shareholders and it is resulted in entrenchment of managers. In this case, managers use the firm's resources for their own private benefits rather than the shareholders'. This is called as managerial entrenchment effect. Following the alignment and entrenchment effects, this study examines whether managerial ownership is effective on cash holding decisions of Turkish firms. To examine the impact of managerial alignment and managerial entrenchment on the cash holdings, the ownership level by managers (MO) and quadratic form of this variable $\left(\mathrm{MO}^{2}\right)$ are used, respectively. Quadratic form of managerial ownership is a proxy for high level of ownership and thus managerial entrenchment in line with the existing literature (Marchica, 2005). When cash holding ratio is used as a dependent variable, a negative coefficient for $\mathrm{MO}$ and a positive coefficient for $\mathrm{MO}^{2}$ are expected. Since high cash holdings cause agency problems of free cash flow (Dittmar et al., 2003), managers should choose less level of cash holdings to behave in line with shareholders' interests. Thus, a negative coefficient for $\mathrm{MO}$ variable is expected. In addition, at higher levels of managerial ownership, managers might hold higher level of cash for their own private benefits at the expense of shareholders'. Therefore, a positive coefficient for $\mathrm{MO}^{2}$ variable is expected.

So far several studies have already analysed the firm specific characteristics that determine the cash holding preferences of firms. Ozkan and Ozkan (2004) examine the impact of managerial ownership besides firm specific characteristics on cash holding preferences of UK firms for the period between 1984 and 1999. Furthermore, although Uyar and Kuzey (2014) have examined the firm specific characteristics that affect cash holding choices of Turkish firms, they have not investigated whether managerial ownership is effective on this choice. As an emerging market Turkish market has different characteristics. Emerging markets have weaker regulatory environment, weak corporate governance and thus low information disclosure level which results in information asymmetry problem between managers and shareholders. As a result, the firms operate in emerging markets come across with costly external financing (Uyar and Kuzey, 2014). Those firms mostly use internal funds in emerging markets ${ }^{1}$. This characteristic of the firms has motivated this study to examine the cash holding choices in an emerging market. The role of agency problem in cash holding decisions is especially examined. According to the GMM regression results, a negative relation between managerial ownership and cash holding is found which is consistent with alignment effect. The ownership of managers aligns the interests of managers with shareholders. However, at higher level of managerial ownership, sample firms prefer higher level of cash holdings which is in line with entrenchment effect. As managerial ownership increases, monitoring and influencing the managers becomes difficult for the outside shareholders. Following this, managerial entrenchment effect is seen.

The remainder of the paper is structured as follows: In Section 2, an overview of the literature on cash holding determinants is provided. Section 3 presents the hypothesis. Section 4 provides details of data and methodology. Section 5 discusses the empirical results. Section 6 includes conclusion.

\section{Literature Review}

Several strands of the extant literature examine the determinants of corporate cash holdings. Kim, Mauer, and Sherman (1998) find that low profitability positively affects corporate cash holdings. Opler et al.(1999) report that small firms, firms with high growth opportunities and firms with risky cash flows hold higher level of cash. Al-Najjar and Belghitar (2011) show that dividends, leverage, growth, size, risk and profit are effective on cash holdings of UK firms. Gill and Shah (2012) identify the cash holdings determinants of Canadian firms and they report that leverage, firm size, net working capital, cash flow and market-to-book ratio are effective on cash holding levels. They also examine the role of corporate governance on cash holdings by showing that CEO duality and larger board size increase cash holdings. Having analyzed the determinants of cash holding in developing countries, Al-Najjar (2013) documents that trade-off theory, pecking order theory and agency cost theory have role in understanding cash holdings in developing countries. He finds that leverage, dividend payout, profitability, asset liquidity and firm size are among the determinants of cash holdings. These results demonstrate that determinants of cash holdings are similar in 
both developed and developing countries. Uyar and Kuzey (2014) show that cash flow and growth opportunities positively affect cash holding level in Turkish non-financial firms. They also report that the amount of capital expenditures, liquid assets used as cash substitute, the degree of tangibility of assets, financial debt ratio and leverage negatively affect cash holding level. Drobetz and Grüninger (2007) find that asset tangibility and firm size negatively affect corporate cash holdings of Swiss firms. Dividend payments and operating cash flows positively affect cash holdings. A non linear relation between managerial ownership and cash holdings is reported which is consistent with alignment affect.

In addition, an important strand of literature focuses on the association between cash holdings and corporate governance structure. The literature that examine the relation between corporate governance and cash holding levels either take into consideration the importance of country level governance quality or firm level governance quality. Some of the studies consider agency problems as an important factor in determining level of cash holdings. The motivation behind this idea is that managers hold large amount of cash in order to pursue their own objectives at the expense of shareholders. Following this motivation, Dittmar, Mahrt-Smith, and Servaes (2003) find that in lower shareholder protection countries managers hold more cash than the managers of the firms in higher shareholder protection countries. La Porta, Lopez-DeSilanes, Shleifer and Vishny (2000) report that firms in the countries with good legal protection of shareholders pay more dividends. By examining the role of creditor rights on cash holdings, Seifert and Gonenc (2015) find a negative relation between creditor rights and cash holdings. They also split their sample into well governed and poorly governed countries. They document a negative relation between creditor rights and cash holdings for well governed countries. In contrast, they find a positive relation between these two variables for poorly governed countries. Kusnadi and Wei (2011) investigate the determinants of cash holdings for international firms. It is found that firms in strong legal protection countries show lower cash flow sensitivity of cash. These firms encounter with less pressure to hoard cash from their internal funds (Kusnadi and Wei, 2011: 738).

Harford, Mansi and Maxwell (2008) find a positive relation between firm level governance quality and cash holdings. They find that firms with strong governance structure prefer to increase dividends which ensures higher payouts in the long term. In contrast, firms with weaker governance structures prefer to hold lower level of cash. Ferreira and Vilela (2004) find that higher investor protection and concentrated ownership result in less cash holdings. They show this result as supportive of the role of managerial discretion agency costs in determining cash holding levels. Chen and Chuang (2009) find that CEO ownership, venture capitalist directors and independent directors positively affect cash holdings in high-tech firms which is consistent with the interest alignment hypothesis. Harford (1999) and Opler et al. (1999) are among the studies which do not find any relation between cash holdings and firm-level corporate governance. Kalcheva and Lins (2007) also find that the firms with higher managerial entrenchment have high level of cash holdings. They also shows an overstated relation between these two variables when country-level shareholder protection is poor. Lee and Lee (2009) report that firms with lower managerial entrenchment, smaller boards and higher board independence have lower level of cash holdings. This result is line with Jensen's (1986) theory which argues that conflicts between managers and shareholders increases when firms have large free cash flows. In these firms, managers give importance to their own interests at the expense of shareholders by using cash for their own interests. Kuan, Li and Chu (2011) examine the relation between cash policy and corporate governance for family controlled firms. Some differences found between family controlled firms and nonfamily controlled firms in terms of their cash holding policies. It is reported that separation of control rights, the director ownership in pledge ratio, the proportion of independent directors and the chair duality have impacts on cash holding policies of family controlled firms. Chen (2008) examines the effect of corporate governance on the cash holdings policies of new economy firms (firms in the computer, software, internet, telecommunications or networking industries) and old economy firms (firms which have limited investment opportunities). It is reported that there is a negative relation between managerial ownership and cash holdings in old economy firms. There is also a positive relation between cash holdings and board independence in new economy firms. 
Pinkowitz, Stulz and Williamson (2003), Harford et al. (2008) and Guney, Ozkan and Ozkan (2007) also find that as shareholder protection decreases cash holdings increase. Gao, Harford and Li (2013) demonstrate greater cash holdings in the public firms which have greater agency conflicts. According to the findings of Ozkan and Ozkan (2004), there is a non-monotonic relation between managerial ownership and cash holdings. They report a negative relation between cash holdings and managerial ownership as managerial ownership increases to $24 \%$. They report a positive relation between managerial ownership and cash holdings as managerial ownership increases to $64 \%$. After this level cash holdings start to decline. By taking into account these studies, this paper contributes to the literature by showing the impact of managerial ownership level on corporate cash holdings of Turkish firms.

Gursoy and Aydogan (2002) define Turkish firms as highly concentrated and family owned firms. The impact of ownership structure is reported both on firm value and risk taking behaviour of firms. Higher concentration results in better market performance but lower accounting performance. Gugler, Mueller and Yurtoglu (2008) examine the positive wealth effect of insider ownership and negative entrenchment effect. Positive wealth effect is measured by the value of a control group's shareholdings and negative entrenchment effect is measured by the fractional holdings. According to their results, wealth effect is positive and entrenchment effect is negative. Bektas and Kaymak (2009) find that ownership concentration and ownership type do not have any impact on the performance of Turkish bank. On the other hand, it is found that the tenure of board members has negative impact on bank performance. Bayrakdaroglu (2010) analyses the relation between managerial ownership and firm performance for IMKB-100 firms. ROA, ROE and Tobin's $Q$ are used as proxies for performance and their relation with managerial ownership is tested. However, insignificant relation between performance and managerial ownership is reported. In addition, Bayrakdaroglu (2010) reports a negative relation between ROA (and ROE) and ownership concentration, and a positive relation between Tobin's $Q$ and ownership concentration. According to Mandaci and Gumus (2010), ownership in Turkish companies is highly concentrated. A positive relation between performance and ownership concentration is reported. In addition, Mandaci and Gumus (2010) find a negative relation between managerial ownership and firm value in line with Demsetz (1983). By using Tobin's Q as a proxy for value, Unlu (2011) investigates whether managerial ownership is effective on IMKB-All firms' performance. However, an insignificant relation between managerial ownership and performance is reported.

\section{Hypothesis}

Jensen (1986) states that managers prefer to hold large amount of cash to pursue their own goals at the expense of those of shareholders. Managers prefer to hold high level of corporate cash since high level of cash holdings also reduce the firm risk and increases managerial discretion (Opler et al., 1999). High cash holdings cause agency problem of free cash flow (Dittmar et al., 2003). This conflict of interests between two parties (managers and shareholders) arising mainly from separation of ownership and control. Besides, a large strand of the literature argues that managerial ownership can align the interests of shareholders with those of managers. When managers have ownership they bear the part of costs of their actions. As a result, it is less likely that managers divert resources away from value maximization (Ozkan and Ozkan, 2004). Since holding cash is costly, a negative relation is expected between managerial ownership and cash holdings.

On the other hand, it is expected that the impact of managerial ownership to be non-monotonic following Morck, Shleifer and Vishny (1988), McConnell and Servaes (1990) and Ozkan and Ozkan (2004). If managers have high level of ownership, entrenchment effect of ownership is seen. As a result, managers choose to hold high level of cash in order to use the cash for their private benefits at the expense of shareholders. Thus, a positive relation between managerial ownership and cash holding is expected at high levels of managerial ownership (entrenchment effect). However, at lower level of managerial ownership, managerial ownership aligns managers' interests with shareholders'. Therefore, cash holding is negatively associated with managerial ownership (alignment effect). 


\section{Research Design}

\subsection{Data}

This study examines the impact of managerial ownership on cash holding levels of the firms listed in Borsa Istanbul-100 index between the period 2005 and 2013. In order to obtain managerial ownership data, yearbooks of Borsa Istanbul firms are used for the period between 2005 and 2008. Managerial ownership data is obtained from Public Disclosure Platform of Turkey for the period between 2009 and 2013. Finnet database, Public Disclosure Platform and Borsa Istanbul website are used to collect information on accounting variables. After excluding financial firms and firm-years for some of the accounting variables and managerial ownership variable, the sample consists of unbalanced panel of 181 firm-years observations.

\subsection{Empirical Model}

To test the hypotheses following regression is estimated:

$$
\mathrm{CASH}_{f, t}=a_{0}+a_{1} M O_{f, t}+a_{2} M O_{f, t}^{2}+X_{f, t}+Y D+\varepsilon
$$

The dependent variable $\mathrm{CASH}_{f, t}$ is the ratio of cash and equivalents to total assets in firm $f$, at time $t$. $M O_{f, t}$ is managerial ownership level in firm f, at time t. $M O_{f, t}^{2}$ is the square of percentage of equity ownership by directors. Following vector of firm-level control variables are used $(X)$ : firm size, dividend payment, market to book ratio, liquidity, leverage, return on equity, cash flow, financial debt ratio and tangibility. YD are year dummies.

This model allows us to test whether there is any managerial alignment or managerial entrenchment effect on the cash holdings of Turkish firms. It is expected that $M O_{f, t}$ coefficient $\left(a_{1}\right)$ to be negative and $M \mathrm{O}^{2}$ coefficient $\left(a_{2}\right)$ to be positive. GMM method of estimation is used to test the hypotheses. Since firms use an adjustment process while determining their target cash levels, dynamic model is used by using GMM. Firms set a target cash level and they take into account the decisions in the previous time period to explain the cash holding decisions in any time period (Ozkan and Ozkan, 2004). Following Ozkan and Ozkan (2004), some estimation problems are determined in dynamic specification. Firstly, since Cash $\mathrm{t}-1$ will be correlated with firm specific effects which do not vary through time, it is necessary to control for firm fixed effects in the dynamic framework. Secondly, firm specific variables might not be exogenous. This means that shocks that have impact on cash holdings of the related firms might affect some of the control variables. In order to solve these problems, an instrumental variables estimation method should be used. Therefore, GMM method of estimation is used where the lagged dependent variable $\left(\mathrm{CASH}_{\mathrm{t}-1}\right)$ used as an endogenous variable and $\mathrm{CASH}_{\mathrm{t}}$ 2, $\mathrm{CFLOW}_{\mathrm{t}-2}, \mathrm{SIZE}_{\mathrm{t}-2}, \mathrm{MB}_{\mathrm{t}-2}, \mathrm{LEV}_{\mathrm{t}-2}$ are used as instruments.

Since the validity of the instruments depends on the absence of second order serial correlation, Arellano-Bond test is used to check for higher order serial correlation and it is found that second order serial correlation is absent. The validity of instruments is tested by Sargan test. Since the null cannot be rejected, the instruments used in this study are valid and are not correlated with the error term.

The extant literature is closely followed in identifying and defining the independent variables:

Managerial Ownership (MO): Managerial ownership is the ratio of ownership by executive directors to the number of shares outstanding at the end of fiscal year. Ozkan and Ozkan (2004) find a negative relation between managerial ownership and cash holding.

Dividend Payment (DIV): Dividend payment is the ratio of dividend payments to total assets. According to trade off theory, there is a negative relation between dividend payments and cash holdings. Firms which pay dividends can trade off the cost of holding cash by decreasing dividend payments (Al-Najjar, 2013). Opler et al. (1999) also states that since a firm paying dividends can raise funds at a low cost by cutting its dividend payments, a negative relation is expected between dividends and cash holdings. 
Firm Size (SIZE): The logarithm of total assets is a proxy for firm size. According to Keynes' (1936) transaction cost motive, a firm's cash holdings increase if the cost of raising it is higher. Since fixed costs are involved in raising outside financing, small firms might find it costlier to raise outside finance (Dittmar et al., 2003). In addition, compared to small firms large firms have less information asymmetry and as a result their managers have better financial flexibility which results with more cash holdings (Al-Najjar, 2013). Since there is a negative relation between information asymmetry and firms size, in turn the cost of external financing, a negative relation between firm size and cash holdings is expected. (Ozkan and Ozkan, 2004; Seifert and Gonenc, 2015; Opler et al., 1999).

Market-to-Book Ratio (MB): This variable is the ratio of the market value of equity to the book value of common equity outstanding. According to Opler et al. (1999), firms which have investment opportunities prefer to hold large amount of cash. If a firm has investment opportunities which can increase its value and does not have enough cash, it may have to pass up these opportunities. Because of this, firms with investment opportunities hold greater amounts of cash not to give up valuable investment opportunities (Ozkan and Ozkan, 2004). Following Smith and Watts (1992) and Jung, Kim and Stulz (1996), market-to-book ratio is used as a proxy for investment opportunities.

Leverage (LEV): Leverage is the ratio of total debt to total assets. A negative relation between leverage and cash holdings is expected. Since leverage is a proxy for the ability of firms to issue debt, firms might use borrowing as a substitute for holding cash (John, 1993). Also according to Baskin (1987), as the ratio of debt financing increases, cost of funds used to invest in liquidity increases. As a result, as debt increases in capital structure of a firm, cash holdings decrease (Ozkan and Ozkan, 2004).

Liquidity (LIQ): Liquidity is net working capital less total cash divided by total assets. Dittmar et al. (2003) argue that liquid assets are substitutes for cash holdings. They show that the firms which have more liquid assets hold less cash. Since liquid assets can be liquidated in the case of cash shortages, they are accepted as substitutes for cash holdings (Ferreira and Vilela, 2004).

Cash Flow (CFLOW): Cash flow is pre-tax profit plus depreciation divided by total assets. Firms with higher cash flow generally do not need to raise cash to pay for future expenses. As a result they hold lower cash flows (Seifert and Gonenc, 2015). In contrast, Ozkan and Ozkan (2004) find that firms with high cash flows prefer to hold large amount of cash. This relation is explained with those firms' preferences for internal over external finance. It is also demonstrated that since cash flow is a proxy for growth opportunities, firms with high cash flows prefer to hold higher cash. The reason of this behaviour is to avoid giving up profitable investment opportunities.

Financial Debt Ratio (FINDEBT): Financial debt ratio is the ratio of total financial debt to total debt. It is known that bank debt has a role in reducing agency conflicts and information asymmetry problems (Diamond, 1984; Boyd and Prescott, 1986; Berlin and Loeys, 1988). This is a result of monitoring power of banks (Ozkan and Ozkan, 2004). Banks can collect the information related to the firm and monitor the firm (Fama, 1985). Following these views, Ozkan and Ozkan (2004) argue that if a bank gives loan to a firm, this signals positive information about that firm. As a result, it is easy to get access to external finance for the firm. This would, in turn, shows that this firm hold less cash. For this reason, a negative relation between bank debt and cash holdings is expected. Rather than using only bank debt, all financial debts is used to examine this relation.

Return on Equity (ROE): Return on equity proxies for the profitability of a firm. It is equal to the ratio of net income to common equity. Profitable firms can pay more dividends; they pay their debts and hold more cash (Al-Najjar, 2013). Since the cost of equity issuance is higher for less profitable firms, they are hesitant to issue equity (Dittmar et al., 2003). Those firms hold less cash and issue debt to finance their projects (Al-Najjar, 2013).

Tangibility (TAN): Tangibility is the ratio of fixed assets to total assets. In line with Drobetz and Grüninger (2007), it is assumed that firms with more tangible assets hold less cash. Drobetz and Grüninger 
(2007) explain this relation with the idea that those assets might be sold in case of cash shortage. They also can be used as collateral in case of debt issuance (Uyar and Kuzey, 2014).

\subsection{Descriptive Statistics}

Panel A of Table 1 shows the time series of cash holdings ratio (CASH) and managerial ownership (MO) ratio between 2005 and 2013. According to Panel A, cash holdings in Turkish firms slightly increased during the sample period from $\% 9$ to $\% 11$. The increased cash holdings might be related with the firms' willingness to increase their capacity to undertake profitable investment opportunities (Almeida, Campello, and Weisbach, 2004). In addition, Acharya, Almeida, and Campello (2005) state that high level of cash balances results with hedging against cash flow deficits and this secures investment. While MO ratio is $9 \%$ in 2005 , it has doubled in 2008 by the $21 \% \mathrm{MO}$ level. And the MO level has fluctuated between $18 \%$ and $21 \%$ until 2013. Both an increase in MO and in CASH is seen in sample firms. However, the increase in MO is more significant than the increase in CASH. This shows that managers prefer to increase their holdings more than the cash holdings of the listed firms.

Table 1. Summary Statistics

Panel A-Time Series of CASH and MO

\begin{tabular}{lrrrrrrrrr}
\hline & 2005 & 2006 & 2007 & 2008 & 2009 & 2010 & 2011 & 2012 & 2013 \\
\hline CASH & 0.09 & 0.09 & 0.1 & 0.1 & 0.1 & 0.12 & 0.11 & 0.11 & 0.11 \\
MO & 0.09 & 0.11 & 0.16 & 0.21 & 0.18 & 0.18 & 0.19 & 0.18 & 0.2 \\
\hline
\end{tabular}

Panel B-Summary Statistics of Firm Specific Characteristics

\begin{tabular}{lcccccc}
\hline Variable & $\mathbf{N}$ & Mean & SD & p25 & p50 & p75 \\
\hline CASH & 603 & 0.10 & 0.11 & 0.03 & 0.07 & 0.14 \\
MO & 230 & 0.17 & 0.2 & 0.01 & 0.08 & 0.26 \\
DIV & 603 & 0.02 & 0.06 & 0 & 0.003 & 0.02 \\
SIZE & 603 & 8.94 & 0.69 & 8.45 & 8.77 & 9.42 \\
MB & 588 & 2.09 & 2.81 & 0.83 & 1.32 & 2.11 \\
LEV & 603 & 0.51 & 0.24 & 0.33 & 0.51 & 0.67 \\
LIQ & 603 & 0.04 & 0.19 & -0.08 & 0.03 & 0.15 \\
CFLOW & 603 & 0.09 & 0.12 & 0.03 & 0.08 & 0.13 \\
FINDEBT & 603 & 0.38 & 0.25 & 0.18 & 0.39 & 0.59 \\
ROE & 603 & 11.58 & 16.4 & 0.77 & 9.04 & 16.83 \\
TAN & 603 & 0.32 & 0.2 & 0.17 & 0.31 & 0.46 \\
\hline
\end{tabular}

Note: Panel A presents the mean values of CASH and MO for the period between 2005 and 2013. Panel B reports the descriptive statistics for the dependent variable and firm level control variables. CASH is cash holdings defined as the ratio of cash and equivalents to total assets. $\mathrm{MO}$ is managerial ownership which is the ratio of ownership by executive directors to the number of shares outstanding at the end of fiscal year. DIV is the dividend payments, defined as the ratio of dividend payments to total assets. SIZE is firm size which is the logarithm of total assets. MB is the market to book ratio, defined as the ratio of the market value of equity to the book value of common equity outstanding. LEV is leverage which is the ratio of total debt to total assets. LIQ is liquidity, defined as net working capital less total cash divided by total assets. CFLOW is cash flow which is equal to pre-tax profit plus depreciation divided by total assets. FINDEBT is financial debt ratio, defined as the ratio of total financial debt to total debt. ROE is return on equity which is equal to the ratio of net income to common equity. TAN is tangibility, defined as the ratio of fixed assets to total assets. Mean, median (p50), standard deviation (SD), $25^{\text {th }}$ percentile (p25) and $75^{\text {th }}$ percentile ( $p 75$ ) are reported. $\mathrm{N}$ is the number of observations. 
Panel B of Table 1 shows the descriptive statistics of the dependent and independent variables that are used in this study. The average firm in the sample has $17 \%$ managerial ownership. On average the sample firms have $10 \%$ cash holdings and $9 \%$ cash flow ratio. Average cash holdings and cash flow ratio levels are consistent with Uyar and Kuzey (2014) who study the cash holdings for Turkish firms. Dividend payments to total asset is $2 \%$,firm size is 8.94 , market to book ratio is 2.09 , leverage is $51 \%$, liquidity is $4 \%$, cash flow is $9 \%$, financial debt ratio is $38 \%$, return on equity is 11.58 and tangibility is $32 \%$.

Table 2 reports the Pearson correlation coefficients of all the variables used in this study. The results do not present any collinearity problem for multivariate analyses. At a univariate level, cash holding is positively correlated with dividend payments. Cash holding is also positively and significantly correlated with firm size and cash flow ratio. Moreover, a negative relation between cash holding and leverage is found. Liquidity, financial debt ratio and tangibility are the other variables which have negative relation with cash holdings. For managerial ownership and market to book ratio, there is not any significant relation at univariate level.

Table 2. Correlation Matrix

\begin{tabular}{lccccccccccc}
\hline & CASH & MO & DIV & SIZE & MB & LEV & LIQ & CFLOW & FINDEBT & ROE & TAN \\
\hline CASH & 1 & & & & & & & & & & \\
MO & -0.08 & 1 & & & & & & & & & \\
DIV & $0.27^{*}$ & $-0.14^{*}$ & 1 & & & & & & & & \\
SIZE & $0.14^{*}$ & -0.02 & $-0.12^{*}$ & 1 & & & & & & \\
MB & -0.01 & -0.11 & $0.26^{*}$ & $-0.14^{*}$ & 1 & & & & & & \\
LEV & $-0.30^{*}$ & $0.12^{*}$ & $-0.22^{*}$ & $0.25^{*}$ & $0.19^{*}$ & 1 & & & & & \\
LIQ & $-0.07^{*}$ & -0.002 & $0.15^{*}$ & $-0.31^{*}$ & -0.04 & $-0.51^{*}$ & 1 & & & & \\
CFLOW & $0.32^{*}$ & -0.11 & $0.35^{*}$ & -0.04 & $0.20^{*}$ & $-0.44^{*}$ & $0.29 *$ & 1 & & & \\
FINDEBT & $-0.27^{*}$ & 0.04 & $-0.23^{*}$ & 0.04 & $-0.11^{*}$ & $0.41^{*}$ & $-0.19^{*}$ & $-0.29 *$ & 1 & & \\
ROE & $0.16^{*}$ & -0.07 & $0.25^{*}$ & $0.12^{*}$ & $0.33^{*}$ & $-0.15^{*}$ & 0.04 & $0.61^{*}$ & $-0.20^{*}$ & 1 & \\
TAN & $-0.14^{*}$ & -0.01 & $-0.11^{*}$ & $-0.14^{*}$ & -0.05 & $-0.09^{*}$ & $-0.12^{*}$ & -0.04 & $0.21 *$ & $-0.14^{*}$ & 1 \\
\hline
\end{tabular}

\section{Empirical Results}

Firstly, a univariate analysis is conducted to estimate the cash holding levels in firms with higher and lower managerial ownership. The aim is to test whether there is lower level of cash holdings in firms with higher managerial ownership. T-test is used in order to test this relation. Panel A of Table 3 shows the t-test results. The sample is separated into two groups. First group (MOlow) includes the firms which have managerial ownership lower than the average value of the managerial ownership, which is 0.17 for sample firms. Second group (MOhigh) includes the firms which have managerial ownership higher than the average value of the managerial ownership in sample. Cash holdings of these two groups of firms are compared. Panel A illustrates a significantly higher level of cash holding in firms with higher level of managerial ownership. Although firms with lower MO have $26 \%$ cash holdings, firms with higher MO have $56 \%$ cash holdings. This result is not consistent with the expectation. The reason of this result might be the entrenchment effect of ownership. Higher managerial ownership might be resulted in the entrenchment effect and those managers make their preferences for their interests at the expense of shareholders. Holding higher level of cash is against the shareholders' preferences but preferable by the entrenched managers.

Moreover, the sample is splitted into four different ownership quartiles and the cash holding levels for each quartile are examined. The reason of this analysis is to investigate the cash holdings in very high level of managerial ownership and very low level of managerial ownership. In each quartile there are 58 observations except quartile 4 which has 56 observations. Panel B of Table 3 reports a cubic relation between 
MO and cash holding. Firstly, cash holding level decreases as managerial ownership increases and the companies reach the lowest level of cash holdings in quartile 2 . Therefore, alignment effect is seen between quartile 1 and quartile 2 . After this point, the relation between $\mathrm{MO}$ and cash holdings becomes positive which supports entrenchment effect. Finally, the cash holding level decreases in the highest MO quartile. Therefore, it can be concluded that the firms with substantial managerial ownership prefer to have lower cash holdings than the firms with moderate managerial ownership (Ozkan and Ozkan, 2004; Chen, 2008; Ferreira and Viela, 2004). The cubic relation between MO and cash holding is in line with the one in Ozkan and Ozkan (2004).

Table 3. Univariate Results

\begin{tabular}{llll}
\hline PANEL A: T-test & & & \\
\hline & & & \\
Variable & Obs & Mean (\%) & SD \\
\hline MOlow & 75 & 0.26 & 0.05 \\
MOhigh & 75 & 0.56 & 0.06 \\
diff & 75 & $-0.30^{* * *}$ & 0.08 \\
\hline
\end{tabular}

PANEL B: Quartiles and CASH

\begin{tabular}{cc}
\hline Managerial Ownership Quartiles & CASH \\
\hline Quartile 1 & $0.163(58)$ \\
Quartile 2 & $0.117(58)$ \\
Quartile 3 & $0.134(58)$ \\
Quartile 4 & $0.117(56)$ \\
\hline
\end{tabular}

Table 4 reports the GMM regression results where the lagged dependent variable $\left(\mathrm{CASH}_{\mathrm{t}-1}\right)$ is the endogenous variable and $\mathrm{CASH}_{\mathrm{t}-2}, \mathrm{CFLOW}_{\mathrm{t}-2}, \mathrm{SIZE}_{\mathrm{t}-2}, \mathrm{MB}_{\mathrm{t}-2}, \mathrm{LEV}_{\mathrm{t}-2}$ are instruments. Consistent with the prediction, a negative significant relation between $\mathrm{MO}$ and $\mathrm{CASH}$ is found. This result indicates that if the firms have managerial ownership, the firms hold less level of cash which is in line with the alignment effect. Therefore, consistent result with the literature is found which shows that managerial ownership aligns the interests of managers with those of shareholders. Since cash holding is costly, managers do not prefer to divert resources away from value maximization. In addition, $\mathrm{MO}^{2}$ has a positive coefficient which supports that firms with higher level of managerial ownership hold more cash to practise their own interests at the expense of shareholders. This result is in line with entrenchment effect and consistent with the findings of existent literature.

Among the independent variables liquidity, firm size and tangibility have negative and significant relation with cash holdings. Since the cost of converting non-cash liquid assets into cash is lower and firms with liquid assets do not have to use capital markets to obtain funds, holding liquid assets is preferable for them (Ozkan and Ozkan, 2004; Ferreira and Vilela, 2004). A negative relation between liquidity and cash holding is found. Thus, non-cash liquid assets can be seen as substitute for cash (Opler et al., 1999). In line with Uyar and Kuzey (2014) and Drobetz and Grüninger (2007), it is found that firms with more tangible assets hold less cash. Those firms might sell their tangible assets when they need cash (Uyar and Kuzey, 2014). As a result, they prefer to hold less cash. In addition, a negative relation between firm size and cash holdings is found. Since a negative relation between information asymmetry and firm size is expected, cost of external financing should be higher for small firms. Therefore, those firms should hold more cash (Ozkan and Ozkan, 2004; Seifert and Gonenc, 2015; Opler et al., 1999). Finally, lagged dependent variable has a positive relation with dependent variable. This proves that firms have a target cash level (Al-Najjar and Belghitar, 2011). 
Table 4. Dynamic Panel Data Estimation Results

\begin{tabular}{|c|c|}
\hline Variable & CASH \\
\hline \multirow[t]{2}{*}{$\mathrm{CASH}_{t-1}$} & $0.565^{* * *}$ \\
\hline & {$[0.000]$} \\
\hline \multirow[t]{2}{*}{ MO } & $-1.239 * * *$ \\
\hline & {$[0.000]$} \\
\hline \multirow[t]{2}{*}{$M O^{2}$} & $1.398 * * *$ \\
\hline & {$[0.007]$} \\
\hline \multirow[t]{2}{*}{ DIV } & -0.105 \\
\hline & {$[0.806]$} \\
\hline \multirow[t]{2}{*}{ SIZE } & $-0.070 * * *$ \\
\hline & {$[0.003]$} \\
\hline \multirow[t]{2}{*}{$M B$} & 0.005 \\
\hline & {$[0.613]$} \\
\hline \multirow[t]{2}{*}{ LEV } & -0.132 \\
\hline & {$[0.166]$} \\
\hline \multirow[t]{2}{*}{ LIQ } & $-0.979 * * *$ \\
\hline & {$[0.000]$} \\
\hline \multirow[t]{2}{*}{ CFLOW } & -0.091 \\
\hline & {$[0.602]$} \\
\hline \multirow[t]{2}{*}{ FINDEBT } & -0.011 \\
\hline & [0.910] \\
\hline \multirow[t]{2}{*}{ ROE(\%) } & -0.002 \\
\hline & [0.331] \\
\hline \multirow[t]{2}{*}{ TAN } & $-0.695 * * *$ \\
\hline & {$[0.000]$} \\
\hline \multirow[t]{2}{*}{ Constant } & $1.121 * * *$ \\
\hline & {$[0.000]$} \\
\hline$N$ & 181 \\
\hline Sargan & 24.16 \\
\hline correlation 1 & $-2.66 * * *$ \\
\hline correlation 2 & -1.24 \\
\hline
\end{tabular}

Note: This table shows the GMM estimation results. Lagged dependent variable $\left(\mathrm{CASH}_{\mathrm{t}-1}\right)$ is the endogenous variable and $\mathrm{CASH}_{\mathrm{t}-2}, \mathrm{CFLOW}_{\mathrm{t}-2}, \mathrm{SIZE}_{\mathrm{t}-2}, \mathrm{MB}_{\mathrm{t}-2}$, $\mathrm{LEV}_{\mathrm{t}-2}$ are instruments. CASH is cash holdings defined as the ratio of cash and equivalents to total assets. $\mathrm{MO}$ is managerial ownership which is the ratio of ownership by executive directors to the number of shares outstanding at the end of fiscal year. $\mathrm{MO}^{2}$ is the square of percentage of equity ownership by directors. The independent variables are defined in Part 4.2. Year dummies are included in the regression. The numbers in brackets are p-values. $* * *, * *$, and $*$ denote significance at the $1 \%, 5 \%$ and $10 \%$ levels, respectively. $\mathrm{N}$ is the number of observations. Correlation 1 and 2 are test statistics for first and second order autocorrelations in residuals, respectively. Sargan test is a test of overidentifying restrictions and it is distributed as chi-square under the null of instrument validity.

\section{Conclusions}

The main contribution of this paper lies in the examination of the influence of the managerial ownership on cash holding decisions of Turkish firms. The results of this study show that average Turkish firm holds $10 \%$ of their assets as cash and equivalents. A slightly increased cash holding is reported between 2005 and 2013. It is found that cash holdings first fall from $16 \%$ to $12 \%$ as managerial ownership increases. This 
finding supports the alignment effects of managerial ownership. Then cash holdings increases to $13 \%$ as managerial ownership increases then falls to $12 \%$ at highest level of managerial ownership. Therefore, a nonmonotonic relation between cash holding and managerial ownership is found for Turkish firms at univariate level.

By using dynamic panel data methodology with GMM analysis, endogeneity problem is controlled that could occur in cash holding investigation. A negative relation between managerial ownership and cash holdings is found. Therefore, an evidence for alignment effect of managerial ownership at multivariate level is showed. When managers have ownership, they use the firm resources to increase the value of the firm and therefore they hold less cash. In addition, the positive relation between quadratic form of managerial ownership and cash holding shows the entrenchment effect of managerial ownership. In this case, managers use the resources for their own interests at the expense of shareholders. The results also indicate that the previous year cash holding positively affects the current year cash level. This results shows that firms have a target cash level.

In sum, a contribution is made to the literature by documenting managerial ownership as a determinant of cash holding for Turkish firms. The findings of this study have some implications for firms in emerging countries. Since they need cash to obtain high level of growth rates, the factors that impact cash holdings should be important for them. Besides the accounting variables, they should also take into consideration the corporate governance variables like managerial ownership. The investors who want to invest in Turkish market might also give importance to findings of this study in order to understand how a corporate governance characteristic is effective on a firm's cash holding decision. Since it is shown in this paper that corporate governance matters in Turkish firms, setting new governance rules that should be applied by the firms can improve the governance quality of Turkish firms. As a result, corporate cash holding levels might be in desirable levels that could avoid agency conflicts. Further research needs to be done by examining the role of other corporate governance variables on cash holdings (i.e. board characteristics and ceo characteristics).

\section{End Notes}

${ }^{1}$ According to Myers and Majluf (1984) in the presence of asymmetric information firms prefer internal over external funds. The information asymmetry disadvantage of external funds is the reason of this choice.

\section{References}

Acharya, V., Almeida, H. and Campello, M. (2005). Is cash negative debt? A hedging perspective on corporate financial policies. London Business School, IFAWorking Paper Series.

Al-Najjar, B., and Belghitar, Y. (2011). Corporate cash holdings and dividend payments: Evidence from simultaneous analysis. Managerial and Decision Economics, 32(4): 231-241.

Al-Najjar,B. (2013). The financial determinants of corporate cash holdings: Evidence from some emerging markets. International Business Review, 22: 77-88.

Almeida, H., Campello, M. and Weisbach, M.S. (2004). The cash flow sensitivity of cash. Journal of Finance, 59: 17771804.

Baskin, J. (1987). Corporate liquidity in games of monopoly power. Review of Economics and Statistics, 69: 312-319.

Bates, T. W., Khale, K. M. and Stulz, R. M. (2009). Why do US firms hold so much more cash than they used to?. Journal of Finance, 64: 1985-2021.

Bayrakdaroglu, A. (2010). Mülkiyet yapısı ve finansal performans: iMKB örneği. Ekonomi Bilimleri Dergisi, 2(2): 11-20.

Bektas, E. And Kaymak, T. (2009). Governance mechanisms and ownership in an emerging market: The case of Turkish banks. Emerging Markets Finance and Trade, 45:6, 20-32

Berlin, M. and Loeys, J. (1988). Bond covenants and delegated monitoring. Journal of Finance, 43: 397-412.

Boyd, J. and Prescott, E.C. (1986). Financial intermediary-coalitions. Journal of Economic Theory, 38: 211-232. 
Chen, Y.R. (2008). Corporate governance and cash holdings: Listed new economy versus old economy firms. Corporate Governance, 16(5): 430-442.

Chen, Y. and Chuang, W. (2009). Alignment or entrenchment? Corporate governance and cash holdings in growing firms. Journal of Business Research, 62: 1200-1206.

Demsetz. H. (1983). The Structure of ownership and the theory of the firm. Journal of Law and Economics, 26:375-390.

Diamond, D.W. (1984). Financial intermediation and delegated monitoring. Review of Economic Studies, 51: $393-414$.

Dittmar, A., Mahrt-Smith, J. and Servaes, H. (2003). International corporate governance and corporate cash holdings. Journal of Financial and Quantitative Analysis, 38: 111-34.

Drobetz, W. and Grüninger, M. C. (2007). Corporate cash holdings: evidence from Switzerland. Financial Markets and Portfolio Management, 21: 293-324.

Fama, E. (1985). What's different about banks?. Journal of Monetary Economics, 15: 29-39.

Ferreira, M. A. and Vilela, A. S. (2004). Why do firms hold cash? Evidence from EMU countries. European Financial Management, 10: 295-319.

Foley, C. F., Hartzell,J.C., Titman,S. and Twite, G. (2007). Why do firms hold so much cash? A tax-based explanation. Journal of Financial Economics, 86: 579-607.

Gao, H., Harford, J. and Li, K. (2013). Determinants of corporate cash policy: Insights from private firms. Journal of Financial Economics, 109: 623-639.

Gill, A. and Shah, C. (2012). Determinants of corporate cash holdings: evidence from Canada. International Journal of Economics and Finance, 4(1): 70-79.

Gugler, K., Mueller,D.C., Yurtoglu, B.B. (2008) Insider ownership, ownership concentration and investment performance: An international comparison. Journal of Corporate Finance, 14:688-705.

Guney, Y., Ozkan, A. and Ozkan, N. (2007). International evidence on the non-linear impact of leverage on corporate cash holding. Journal of Multinational Financial Management, 17: 45-60.

Gursoy, G. and Aydogan, K. (2002). Equity ownership structure, risk taking and performance. Emerging Markets Finance and Trade, 38(60: 6-25.

Harford, J. (1999). Corporate cash reserves and acquisitions. Journal of Finance, 54: 1969-1997.

Harford, J., Mansi, S. A. and Maxwell, W. F. (2008). Corporate governance and firm cash holdings in the US. Journal of Financial Economics, 87: 535-55.

Jensen, M. (1986). Agency costs of free cash flow, corporate finance and takeovers. American Economic Review, 76: 323-329.

John, T.A. (1993). Accounting measures of corporate liquidity, leverage, and costs of financial distress. Financial Management, 22: 91-100.

Jung, K., Kim, Y. and Stulz, R. (1996). Timing, investment opportunities, managerial discretion, and the security issue decision. Journal of Financial Economics, 42: 159-185.

Kalcheva, I., and Lins, K.V. (2007). International evidence on cash holdings and expected managerial agency problems. Review of Financial Studies, 20: 1087-112.

Keynes, J.M. (1936). The General Theory of Employment, Interest and Money, Harcourt Brace,London.

Kim, C. S., Mauer, D. C. and Sherman, A. E. (1998). The determinants of corporate liquidity: theory and evidence. Journal of Financial and Quantitative Analysis, 33: 305-34.

Kuan, T.H., Li, C.H. and Chu, S.H. (2011). Cash holdings and corporate governance in family-controlled firms. Journal of Business Research, 64: 757-764.

Kusnadi, Y. and Wei, K. C. (2011). The determinants of corporate cash management policies: Evidence from around the world. Journal of Corporate Finance, 17: 725-740.

La Porta, R., Lopez-De-Silanes, F., Shleifer, A. and Vishny, R. (2000). Investor protection and corporate governance. Journal of Financial Economics: 58: 3-27.

Lee, K.W. and Lee, C. (2009). Cash holdings, corporate governance structure and firm valuation. Review of Pacific Basin Financial Markets and Policies, 12(3): 475-508.

Mandaci, P. and Gumus, G. (2010). Ownership concentration, managerial ownership and firm performance: Evidence from Turkey. South East European Journal of Economics and Business, 5(1): 57-66 
Marchica, M.T. (2005). Debt maturity and characteristics of ownership structure: An empirical Investigation of UK firms. University of York Discussion Papers in Economics, No: 2005/29.

McConnell, J.J. and Servaes, H. (1990). Additional evidence on equity ownership and corporate value. Journal of Financial Economics, 27: 595-612.

Morck, R., Shleifer, A. and Vishny, R. (1988). Management ownership and market valuation: An empirical analysis. Journal of Financial Economics, 20: 293-315.

Myers, S.C. and Majluf, N.S. (1984). Corporate financing and investment decisions when firms haveinformation that investors do not have. Journal of Financial Economics, 13: 187-221.

Opler, T., Pinkowitz, L., Stulz, R. and Williamson, R. (1999). The determinants and implications of cash holdings. Journal of Financial Economics, 52: 3-46.

Ozkan, A. and Ozkan, N. (2004). Corporate cash holdings: an empirical investigation of UK companies. Journal of Banking and Finance, 28: 2103-34.

Pinkowitz, L., Stulz, R. and Williamson, R. (2003). Why do firms in countries with poor protection of investor rights hold more cash?. Working paper, Georgetown University.

Pinkowitz, L., Stulz, R. and Williamson, R. (2006). Do firms in countries with poor protection of investor rights hold more cash?. Journal of Finance, 61: 2725-2751.

Seifert, B. and Gonenc, H. (2015). Creditor rights, country governance, and corporate cash holdings. Journal of International Financial Management and Accounting, Forthcoming

Smith, C. and Watts, R. (1992). The investment opportunity set and corporate financing, dividend and compensation policies. Journal of Financial Economics, 32: 263-92.

Unlu, U. (2011). Yönetici sahipliği ve firma değeri: IMKB İçin ampirik bir uygulama. Ankara Üniversitesi SBF Dergisi, 66(2): 201-214.

Uyar, A. and Kuzey, C. (2014). Determinants of corporate cash holdings: evidence from the emerging market of Turkey. Applied Economics, 46(9): 1035-1048. 
This Page Intentionally Left Blank 